\title{
Virulence of transparent and opaque colony types of Neisseria gonorrhoeae for the genital tract of mice
}

\author{
E. KITA, N. KATSUI, M. EMOTO, M. SAWAKI*, D. OKU, FUMIKO NISHIKAWA, \\ AKIKO HAMURO and S. KASHIBA
} Department of Bacteriology and $\cdot 2 n d$ Department of Internal Medicine, Nara Medical University 840, Shijyocho,
Kashihara, Nara 634, Japan

\begin{abstract}
Summary. The virulence of transparent $(\mathrm{Tr})$ and opaque $(\mathrm{Op})$ colony types of Neisseria gonorrhoeae in the genital tract of female mice was evaluated at two stages of oestrous. Isogenic pairs of $\operatorname{Tr}$ and $O p$ variants were isolated from $N$. gonorrhoeae strain 57-120. Both variants exhibited a T2 morphology, but only the Op variant possessed protein II (P. II) in outer-membrane fractions. When administered by intravaginal inoculation Op gonococci were highly infective only for mice in late pro-oestrous, whereas $\mathrm{Tr}$ gonococci were virulent for mice at both late pro-oestrous and dioestrous. Gonococci recovered from the uterus were of both $\mathrm{Tr}$ and $\mathrm{Op}$ phenotypes in equal proportions when mice were infected at dioestrous with $\mathrm{Tr}$ cells. In contrast, $>\mathbf{9 0} \%$ of recovered colonies were of Op phenotype when mice were infected at late pro-oestrous with either $\mathrm{Op}$ or $\mathrm{Tr}$ cells. These results indicate that the virulence of gonococci for the genital tract of female mice differs from that for the chicken embryo. Furthermore, gonococcal survival in the female genital tract might be attributable to phase variation from $\mathrm{Tr}$ to $\mathrm{Op}$ phenotypes.
\end{abstract}

\section{Introduction}

Recent investigations of the virulence of Neisseria gonorrhoeae have focused on several properties of the macromolecular components on the cell surface. Amongst surface structures implicated in the pathogenesis of gonococcal infection, pili and protein II (P. II) have received particular attention because of their ability to undergo dramatic alterations in their structural characteristics. ${ }^{1-6}$

Pili are thought to promote adhesion of gonococci to epithelial cells ${ }^{7}$ as a primary step in infection, thus anchoring the bacteria to the mucosa. ${ }^{8,9} \mathrm{P}$. II is also considered to contribute ${ }^{10-14}$ to direct contact between the epithelium and bacterial surface ${ }^{15}$ as well as to inter-gonococcal adhesion. ${ }^{16,17}$ Moreover, several studies have revealed that alterations in pili and P. II molecules substantially affect the adhesive properties of the bacteria for different cell types. ${ }^{18-20}$

Clinical isolates of gonococci can be classified not only into pilate and non-pilate phenotypes, but also into opacity variants on the basis of colonial morphology. ${ }^{21}$ Opaque-colony $(\mathrm{Op})$ gonococci have one or more P. II proteins, ${ }^{22,23}$ whereas colourless, transparent $(\mathrm{Tr})$ colonies generally contain bacteria whose outer membranes are devoid of these proteins. Gonococci possessing certain P. II proteins show not only increased colonial opacity but also decreased sensitivity to steroid sex hormones; in particular, oestrogen

Received 20 June 1990; accepted 10 Oct. 1990. enhances the growth of Op gonococci in vitro and progesterone inhibits their growth. ${ }^{24}$

Colonies of gonococci isolated from cervical cultures range from fully opaque to transparent, with some intermediate degrees of opacity, and the colonial phase variation is associated with the menstrual cycle. ${ }^{25}$ Gonococci expressing P. II are associated only with infections localised to the urogenital mucosa. This strongly suggests that the expression of P.II in vivo may be associated with the pathogenesis of gonococcal infection in the female genital tract.

In the present study we compared the virulence of P. II-expressing (Op) and P. II-non-expressing (Tr) variants of the same strain (isogenic pairs) in our mouse model of gonococcal genital infection. ${ }^{26}$

\section{Materials and methods}

\section{Organisms}

Isogenic Op and $\operatorname{Tr}$ variants were isolated from $N$. gonorrhoeae strain $57-120^{27}$ following the criteria of Swanson. ${ }^{21}$ Kellogg's colonial type ${ }^{28}$ was determined by the method of Juni and Heym, ${ }^{29}$ and type 2 colony morphology for both $\mathrm{Op}$ and $\mathrm{Tr}$ variants was selected. Both variants were passaged sequentially daily by single-colony transfer on clear phenotyping agar, ${ }^{10}$ until a high degree of colony stability of each variant was ensured. P. II proteins were identified by sodium dodecyl sulphate-polyacrylamide gel electrophoresis 
of whole-cell lysates and by apparent change in molecular weight when heated. The degree of pilation was confirmed by transmission electronmicroscopy. Both variants were stored at $-80^{\circ} \mathrm{C}$ in gelatin disks, ${ }^{30}$ so that the same batch of each variant could be used throughout the study.

For each experiment, one of the disks was dissolved in $1 \mathrm{ml}$ of Mueller-Hinton Broth (Difco) and cultured on GC Agar Base (Difco) enriched with IsoVitalex (Baltimore Biological Laboratories) $2 \% \mathrm{v} / \mathrm{v}$ at $37^{\circ} \mathrm{C}$ for $18 \mathrm{~h}$ in air $+\mathrm{CO}_{2} 5 \%$. Organisms grown on GC agar were transferred to the liquid medium and incubated overnight at $37^{\circ} \mathrm{C}$ with continuous rotation as described previously. ${ }^{27}$ After incubation for $24 \mathrm{~h}$, bacteria were harvested and washed several times with phenol red-free Eagles' Minimal Essential Medium (MEM; Flow Laboratories, McLean, VA, USA) supplemented with 20 mM HEPES (HEPES-MEM); washed bacteria were suspended in HEPES-MEM. Subculture on GC agar of each variant grown in the liquid medium showed that each phenotype was preserved ( $>98 \%$ viability) during incubation for $24 \mathrm{~h}$ in liquid culture. The concentration of the gonococcal inoculum was quantified spectrophotometrically, and confirmed by plate counts.

\section{Animals}

Female virgin mice of the ddY strain, 10-12 weeks old, were used throughout the investigation. They were fed a commercial laboratory animal diet and water ad libitum. The stages of their oestrous cycle were determined by the vaginal smear technique ${ }^{31}$ as described previously. ${ }^{26}$

\section{Inoculation procedure}

Intravaginal inoculation of gonococci was performed as described previously. ${ }^{26}$ The vaginal openings were disinfected with alcohol before inoculation. Gonococci were suspended in pre-warmed HEPESMEM containing gelatin $1 \% \mathrm{w} / \mathrm{v}$ at a concentration of $10^{8} \mathrm{cfu} / \mathrm{ml}$, and $20 \mu \mathrm{l}$ of the suspension were inoculated into the vagina with a sterile tip on a micropipette (Pippetman).

\section{Recovery of gonococci from the genital tract}

At regular intervals, mice were killed by cervical dislocation. The vagina was washed twice with $50 \mu \mathrm{l}$ of pre-warmed HEPES-MEM by means of a micropipette; washings were pooled and $20 \mu$ lof the pooled fluid was cultured on GC agar with vancomycin $3 \mathrm{mg} /$ $\mathrm{L}$, colistin $7.5 \mathrm{mg} / \mathrm{L}$, and nystatin $12500 \mathrm{U} / \mathrm{L}$ (TM agar) at $37^{\circ} \mathrm{C}$ in air $+\mathrm{CO}_{2} 5 \%$ for $48 \mathrm{~h}$. Thereafter, the cervico-vaginal region and uterine horns were removed aseptically. The uterine body and horn were dissected longitudinally. Half of the uterine body with its attached uterine horn was placed in a petri dish (6 $\mathrm{cm}$ diameter) containing $1.0 \mathrm{ml}$ of HEPES-MEM, and they were rinsed several times with fresh HEPES-
MEM. To determine the numbers of gonococci loosely attached to the surface of the uterus, $50 \mu$ l of the first wash obtained by rinsing the uterine tissue was cultured on $\mathrm{TM}$ agar at $37^{\circ} \mathrm{C}$ in air $+\mathrm{CO}_{2} 5 \%$ for $48 \mathrm{~h}$. The washed tissues were then homogenised in $1.0 \mathrm{ml}$ of HEPES-MEM, supplemented with saponin $0.5 \% \mathrm{w} / \mathrm{v}$, with a teflon homogeniser. Dilutions of the homogenate $(20 \mu \mathrm{l})$ were cultured on TM agar at $37^{\circ} \mathrm{C}$ in air $+\mathrm{CO}_{2} 5 \%$ for $48 \mathrm{~h}$ to quantitate the numbers of viable gonococci.

The contralateral uterine horn and body were fixed with formaldehyde $3.5 \% \mathrm{v} / \mathrm{v}$, embedded in paraffin, and sectioned for haematoxylin and eosin (HE) staining. For scanning electronmicroscopy (SEM), tissues were fixed with glutaraldehyde $1 \% \mathrm{v} / \mathrm{v}$ in $0.15 \mathrm{M}$ sodium cacodylate buffer ( $\mathrm{pH} 7 \cdot 2$ ) immediately after washing with HEPES-MEM. The critical point method was employed for drying the specimens which were then examimed with a JEOL scanning electronmicroscope (JSM-T20) at $20 \mathrm{kV}$ after coating the specimens with gold-palladium ( $\mathrm{Au} \mathrm{60 \% ,} \mathrm{Pd} \mathrm{40 \% )}$ while rotating them in a vacuum evaporator.

\section{Direct immunofluorescence}

Antiserum to $N$. gonorrhoeae strain $57-120$ was raised in rabbits by injecting formalin-killed organisms emulsified in Freund's complete adjuvant subcutaneously three times at 12-day intervals. The rabbits were bled 7 days after the final injection. Fluoresceinlabelled rabbit anti- $N$. gonorrhoeae strain 57-120 immunoglobulin was prepared by the method of Johnson et al. ${ }^{32}$ The labelled immunoglobulin was pre-absorbed with normal mouse uterine homogenates. Slides of uterine sections were stained with this pre-absorbed fluorescein-labelled antibody and then observed with an Olympus epifluorescence ultraviolet microscope. Control slides of sections of uninfected mouse uterus showed no specific immunofluorescence.

\section{Statistical analysis}

The levels of significance for the observed frequencies were determined by Student's $t$ test.

\section{Results}

\section{Comparison of infectivity of $O p$ and $T r$ variants}

The infectivity of both variants for the mouse uterus was compared in mice at late pro-oestrous and at dioestrous stages. The results are summarised in table I. Both phenotypes were highly infective for mice at late pro-oestrous; Op variants showed greater infectivity than $\mathrm{Tr}$ variants. In contrast, at dioestrous, $\mathrm{Op}$ variants showed low infectivity, whereas $\operatorname{Tr}$ variants exhibited significantly greater infectivity.

\section{Enumeration of gonococci in the uterus}

The number of gonococci recovered from uterine homogenates was determined (fig. 1). In mice that had 
Table I. Relationship between oestrous cycle of mice and infectivity of colonial variants of $N$. gonorrhoeae $57-120$

\begin{tabular}{|c|c|c|c|c|}
\hline \multirow{3}{*}{$\begin{array}{c}\text { Experi- } \\
\text { ment } \\
\text { no. }\end{array}$} & \multicolumn{4}{|c|}{$\begin{array}{l}\text { Number of mice }(/ 10) \text { with positive cultures } \\
\text { for gonococci } 7 \text { days after infection with }\end{array}$} \\
\hline & \multicolumn{2}{|c|}{ Op variant at } & \multicolumn{2}{|c|}{ Tr variant at } \\
\hline & $\begin{array}{c}\text { late } \\
\text { pro-oestrous }\end{array}$ & dioestrous & $\begin{array}{c}\text { late } \\
\text { pro-oestrous }\end{array}$ & dioestrous \\
\hline I & 10 & 1 & 7 & 5 \\
\hline II & 9 & 0 & 7 & 6 \\
\hline III & 10 & 0 & 8 & 5 \\
\hline
\end{tabular}

been infected at late pro-oestrous with either variant, the number of gonococci recovered from homogenates increased slowly, but steadily, from $12 \mathrm{~h}$ to 7 days after inoculation, although the number of bacteria in the mice injected with the Op variant remained about $1.0 \log _{10}$ higher than in the mice injected with the $\mathrm{Tr}$ variant at each time point. However, in mice that had been infected at dioestrous with either $\mathrm{Op}$ or $\mathrm{Tr}$ variants, gonococci were not recovered $12 \mathrm{~h}$ after inoculation. After $96 \mathrm{~h}$, gonococci were recovered only from mice that had been infected with the $\mathrm{Tr}$ variant and the number of bacteria remained, at most, $100 \mathrm{cfu}$ per uterus. Gonococci were not recovered from mice that had been infected at dioestrous with the Op variant.

The number of gonococci recovered from the uterine washings was greatest at $24 \mathrm{~h}$ after inoculation in mice infected at late pro-oestrous with either variant, and in those infected at dioestrous with the $\operatorname{Tr}$ variant (table II). Thereafter, the number of gonococci in washings decreased with time. Furthermore, no significant colonial phase variation occurred over a 7day period. In mice infected at dioestrous with the $\mathrm{Op}$ variant, cultures were negative over a 7-day period.

\section{Pathological changes in vaginal discharge}

Smears of the vaginal discharge from mice infected at dioestrous with either variant demonstrated the

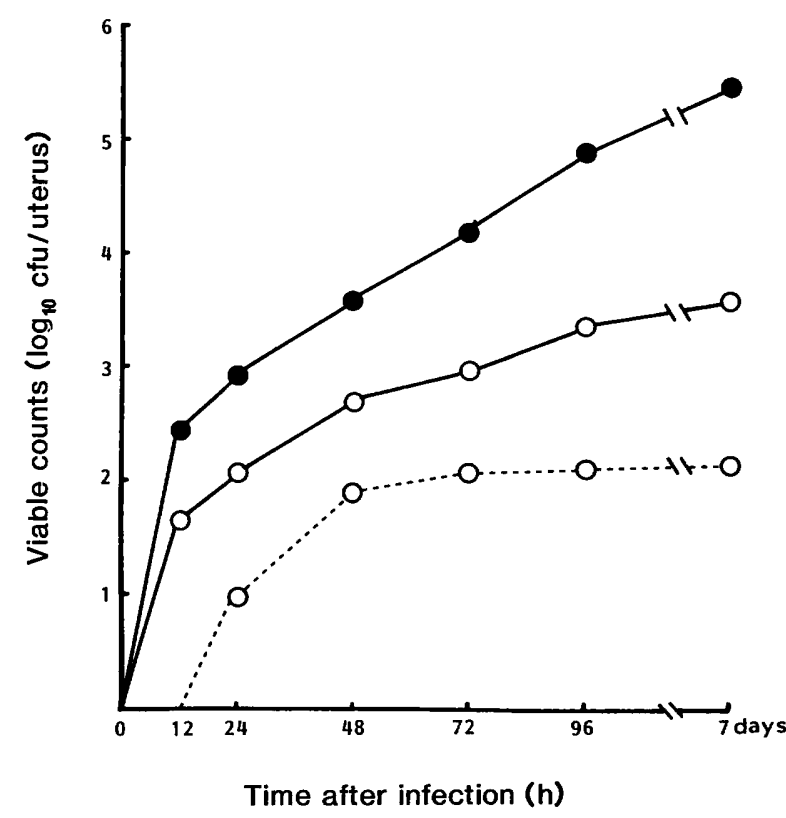

Fig. 1. Viable counts of $N$. gonorrhoeae in uterus of mice after intravaginal inoculation: $\bullet-\bullet$, infected at late pro-oestrous with Op variant; $\circ-\circ$, infected at late pro-oestrous and $0--\circ$ at dioestrous with $\operatorname{Tr}$ variant.

presence of gonococci attached to or engulfed by polymorphonuclear leucocytes (PMNL) until $48 \mathrm{~h}$ after infection (fig. 2a). Thereafter, the number of gonococci decreased rapidly with time, and PMNL infiltration continued over a 7-day period (fig. $2 b$ ). These changes were common to both colonial types.

However, when mice at late pro-oestrous were infected with either variant, PMNL infiltration was not discernable throughout the 7-day experiment, but a large number of gonococci were seen attached to epithelial cells (fig. 2c). Furthermore, gonococci were recovered from vaginal discharges over a 7-day period from mice infected at late pro-oestrous with either variant, and from mice infected at dioestrous with the Tr variant, whereas cultures were positive only for 2 days in mice infected at dioestrous with the $O p$ variant (table III). The predominant colonial type of gonococci recovered from the vagina was the same as that of gonococci recovered from the uterine washings.

Table II. Recovery of $N$. gonorrhoeae from uterine washings after infection*

\begin{tabular}{|c|c|c|c|c|c|c|}
\hline \multirow{2}{*}{$\begin{array}{l}\text { Colony } \\
\text { type of } \\
\text { inoculum }\end{array}$} & \multirow{2}{*}{$\begin{array}{c}\text { Stage of } \\
\text { oestrous cycle } \\
\text { at inoculation }\end{array}$} & \multicolumn{5}{|c|}{ Mean (SD) number of gonococci $\left(\log _{10} \mathrm{cfu}\right)$ in washings on day (after inoculation) } \\
\hline & & 1 & 2 & 3 & 4 & 7 \\
\hline Op & $\begin{array}{l}\text { Late pro-oestrous } \\
\text { Dioestrous }\end{array}$ & $\begin{array}{c}3.8 \mathrm{SD} 0.5 \\
(\mathrm{Op}=100 \%) \dagger \\
-\end{array}$ & $\begin{array}{c}3 \cdot 2 \mathrm{SD} 0 \cdot 3 \\
(\mathrm{Op}=100 \%) \\
-\end{array}$ & $\begin{array}{c}2.8 \mathrm{SD} 0.4 \\
(\mathrm{Op}>96 \%) \\
-\end{array}$ & $\begin{array}{c}2 \cdot 2 \mathrm{SD} 0 \cdot 2 \\
(\mathrm{Op}>96 \%) \\
-\end{array}$ & $\begin{array}{c}1.8 \mathrm{SD} 0.3 \\
(\mathrm{Op}>92 \%) \\
-\end{array}$ \\
\hline $\operatorname{Tr}$ & $\begin{array}{l}\text { Late pro-oestrous } \\
\text { Dioestrous }\end{array}$ & $\begin{array}{c}2.4 \text { SD } 0.4 \\
(\mathrm{Tr}=100 \%) \\
2 \cdot 0 \mathrm{SD} 0 \cdot 2 \\
(\mathrm{Tr}=100 \%)\end{array}$ & $\begin{array}{c}2.0 \text { SD } 0.3 \\
(\mathrm{Tr}>86 \%) \\
1.8 \mathrm{SD} 0.4 \\
(\mathrm{Tr}>92 \%)\end{array}$ & $\begin{array}{c}1.8 \mathrm{SD} 0.4 \\
(\mathrm{Tr}>68 \%) \\
1.6 \mathrm{SD} 0.2 \\
(\mathrm{Tr}>74 \%)\end{array}$ & $\begin{array}{c}1.5 \text { SD } 0.3 \\
(O p>76 \%) \\
1.3 \text { SD } 0.2 \\
(O p>68 \%)\end{array}$ & $\begin{array}{c}1 \cdot 1 \text { SD 0.4 } \\
(O p>90 \%) \\
0.9 \text { SD } 0.3 \\
(O p>90 \%)\end{array}$ \\
\hline
\end{tabular}

-, None recovered.

*Data from three experiments with 10 mice in each.

$\dagger$ Numbers in parenthesis indicate percentage of the predominant phenotype. 

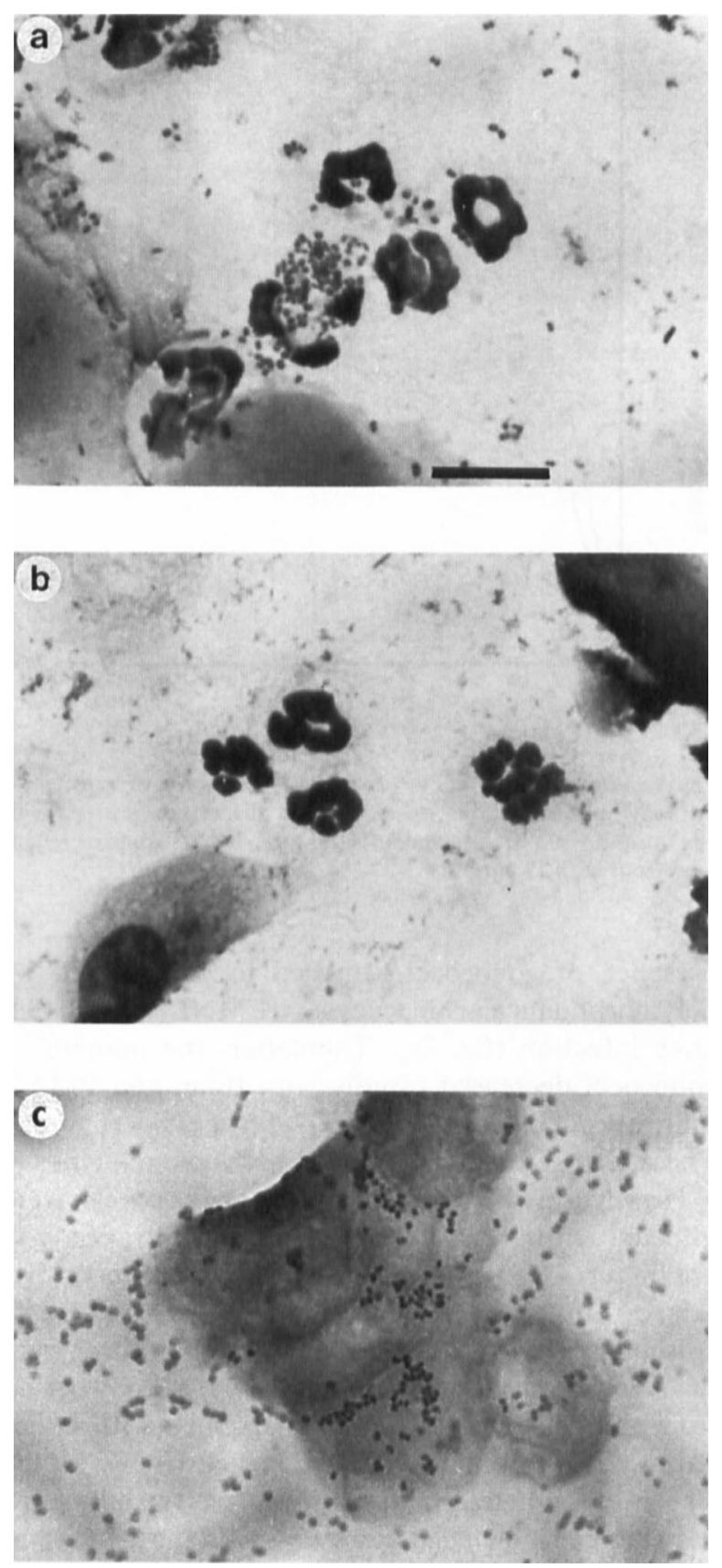

Fig. 2. Cytosmears of vaginal discharge: (a) $48 \mathrm{~h}$ and (b) 7 days after mice at dioestrous were infected with $\operatorname{Tr}$ variant; (c) $48 \mathrm{~h}$ after mice at late pro-oestrous were infected with Op variant (bar, $10 \mu \mathrm{m}$ ).
However, in mice infected at dioestrous with the Op variant, Op was the predominant type (about $64 \%$ of total colonies) only on day 1 and $>66 \%$ of colonies had become Tr variants on day 2 .

\section{Histological study}

No remarkable histological changes were observed by light microscopy in sections of uterus from mice infected with either variant until $24 \mathrm{~h}$ after infection, regardless of the stage of the oestrous cycles at which the mice were infected. The appearance was no different from that of sections of uterus from mice matched for oestrous-cycle stage.

In mice infected at dioestrous with the Tr variant, PMNL infiltration of the mucosal epithelium and subepithelium in the uterus was significantly increased $48 \mathrm{~h}$ after infection (fig. 3a), compared with the normal changes in PMNL numbers associated with changes in the oestrous cycle (fig. 3b). After $72 \mathrm{~h}$, only slight oedema was observed in the subepithelial stroma with minimal infiltration, and the epithelial cell layer was not affected (fig. 3c). No histopathological changes were detected in the uterus of mice infected with the Op variant when animals were infected at dioestrous.

In contrast, when mice were infected at late prooestrous with either variant, there was minimal acute inflammatory reaction within $48 \mathrm{~h}$ and only slight oedema was seen in the subepithelial stroma (fig. 3d). Gonococci were detected by direct fluorescent staining in the epithelium and submucosal stroma (fig. 3e). The most striking change in mice infected at this stage was detected $72 \mathrm{~h}$ after inoculation; it was characterised by the presence of multiple gonococcal clusters in the subepithelial stroma (fig. $3 \mathrm{f}$ ). This change was more evident in the mice infected with the Op variant than in those infected with the Tr variant.

Uterine tissues from all infected mice were also examined by SEM. Within $4 \mathrm{~h}$ of inoculation, gonococci were seen to be attached to the surface of the epithelium of the uterine body (fig. 4a), regardless of colonial phenotype of the inoculum, when mice were infected at late pro-oestrous. Normal bacterial flora were visible on the surface of the uterine body, but the

Table III. Recovery of $N$. gonorrhoeae from vaginal washings*

\begin{tabular}{|c|c|c|c|c|c|c|}
\hline \multirow{2}{*}{$\begin{array}{l}\text { Colony } \\
\text { type of } \\
\text { inoculum }\end{array}$} & \multirow{2}{*}{$\begin{array}{c}\text { Stage of } \\
\text { oestrous cycle } \\
\text { at inoculation }\end{array}$} & \multicolumn{5}{|c|}{ Mean (SD) number of gonococci ( $\log _{10} \mathrm{cfu}$ ) in washings on day (after inoculation) } \\
\hline & & 1 & 2 & 3 & 4 & 7 \\
\hline Op & $\begin{array}{l}\text { Late pro-oestrous } \\
\text { Dioestrous }\end{array}$ & $\begin{array}{c}5 \cdot 2 \text { SD } 1 \cdot 4 \\
(O p=100 \%) \\
1 \cdot 2 \text { SD } 0 \cdot 4 \\
(O p>64 \%)\end{array}$ & $\begin{array}{c}4.8 \text { SD } 1.6 \\
(O p=100 \%) \\
0.8 \text { SD } 0.2 \\
(\operatorname{Tr}>66 \%)\end{array}$ & $\begin{array}{c}3 \cdot 1 \mathrm{SD} 1 \cdot 2 \\
(\mathrm{Op}=100 \%) \\
-\end{array}$ & $\begin{array}{c}2.5 \mathrm{SD} 0.8 \\
(\mathrm{Op}>96 \%) \\
-\end{array}$ & $\begin{array}{c}2 \cdot 2 \mathrm{SD} 0.4 \\
(\mathrm{Op}>90 \%) \\
-\end{array}$ \\
\hline $\mathrm{Tr}$ & $\begin{array}{l}\text { Late pro-oestrous } \\
\text { Dioestrous }\end{array}$ & $\begin{array}{c}3 \cdot 8 \operatorname{SD~} 1 \cdot 2 \\
(\operatorname{Tr}=100 \%) \\
2 \cdot 2 \operatorname{SD~} 1 \cdot 7 \\
(\mathrm{Tr}=100 \%)\end{array}$ & $\begin{array}{c}2.4 \text { SD } 1.5 \\
(\operatorname{Tr}=100 \%) \\
1.9 \operatorname{SD~} 0.8 \\
(\mathrm{Tr}=100 \%)\end{array}$ & $\begin{array}{l}2.0 \text { SD } 0.7 \\
(\operatorname{Tr}>52 \%) \\
1.5 \operatorname{SD~} 0.5 \\
(\operatorname{Tr}>80 \%)\end{array}$ & $\begin{array}{c}1.7 \mathrm{SD} 0.2 \\
(\mathrm{Op}>80 \%) \\
1.2 \mathrm{SD} 0.3 \\
\left(\mathrm{Op}>70^{\circ} \%\right)\end{array}$ & $\begin{array}{c}1.1 \text { SD } 0.2 \\
(O p>90 \%) \\
0.9 \text { SD } 0.1 \\
(O p>88 \%)\end{array}$ \\
\hline
\end{tabular}

* See footnotes to table II. 

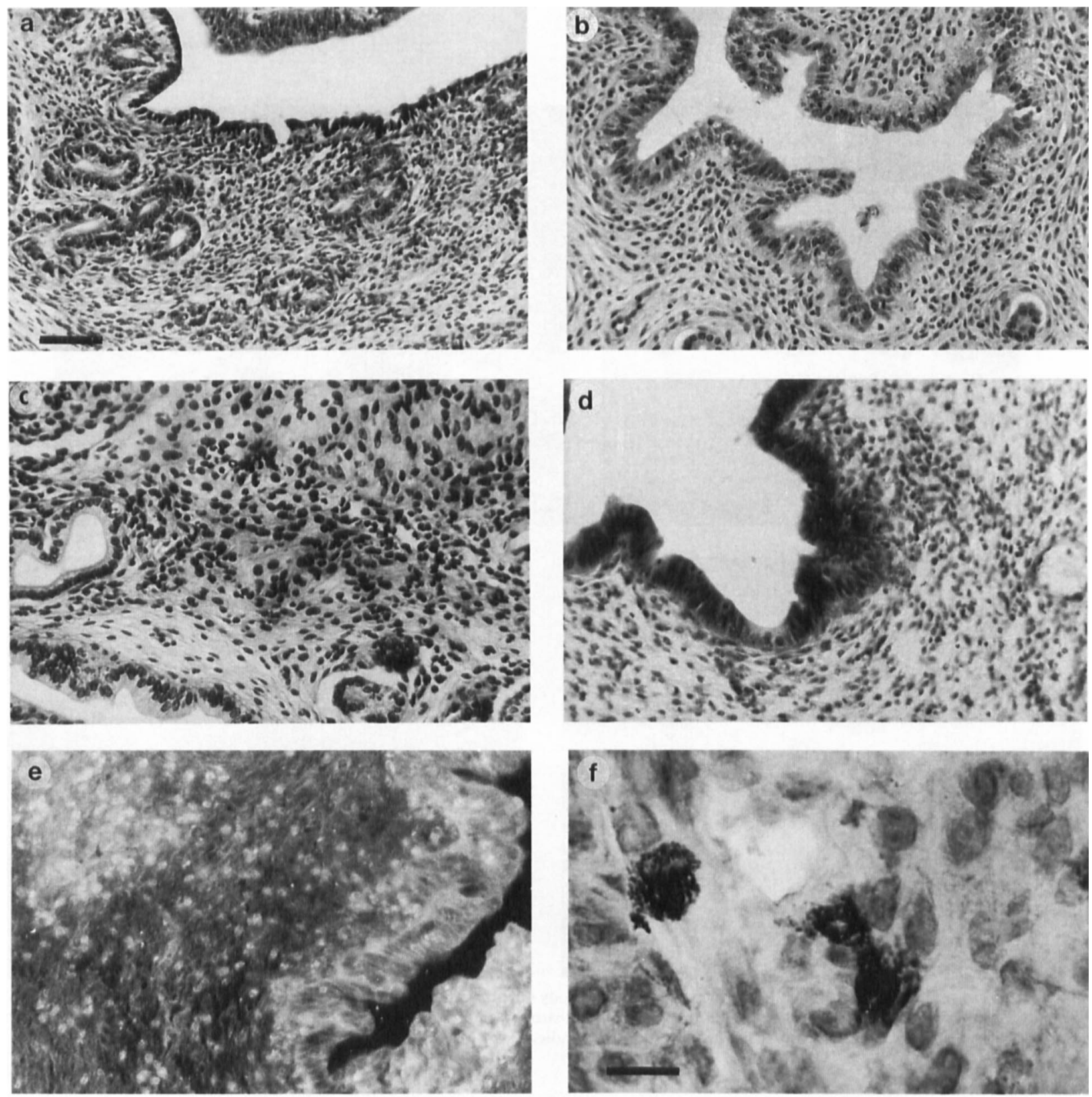

Fig. 3. Histological changes in the uterus: (a) $48 \mathrm{~h}$ after mice at dioestrous were infected with Op variant cocci; (b) control uterus from a mouse at the same stage of oestrous; (c) $72 \mathrm{~h}$ after mice at dioestrous were infected with Tr variant; (d) $48 \mathrm{~h}$ after mice at late pro-oestrous were infected with Op variant; (e) as (d), but the gonococci were detected by direct immunofluorescent staining; (f) $72 \mathrm{~h}$ after mice at late pro-oestrous were infected with Op variant (bar, $100 \mu \mathrm{m}$ in a, $10 \mu \mathrm{m}$ in f).

surface was not affected by the attachment of gonococci. Gonococci were seen on the surface of the uterine horn from as early as $12 \mathrm{~h}$ after inoculation. The surface to which gonococci were adherent was devoid of microvilli, and appeared rough compared to uninfected sites (fig. 4b). Phagocytic cells were not detected on the surface of the uterine horn of mice infected at late pro-oestrous, and gonococci seemed to be sinking into the mucosal surface $24 \mathrm{~h}$ after inoculation (fig. 4c). This change was common to infections with both variants.

However, when mice were infected at dioestrous, gonococci were not detected on the surface of the uterine body until $24 \mathrm{~h}$ after inoculation, regardless of the colonial phenotype of the inoculum. Thereafter, gonococci were seen on the surface of the uterine horn with leucocytes migrating towards the bacteria (fig. $4 d$ ), but only in mice infected with the $\operatorname{Tr}$ variant.

\section{Colonial phenotypes of recovered gonococci}

The number of gonococci in the uterus 7 days after inoculation was about $2 \log _{10}$ higher in mice infected with the $O p$ variant than in those infected with the $\mathrm{Tr}$ variant when animals were infected at late prooestrous (table IV). Furthermore, $>90 \%$ of gonococci recovered from mice infected at late pro-oestrous were of Op phenotype and $<5 \%$ of colonies represented the Tr phenotype, regardless of the colonial phenotype of the gonococci inoculated. In contrast, when mice 

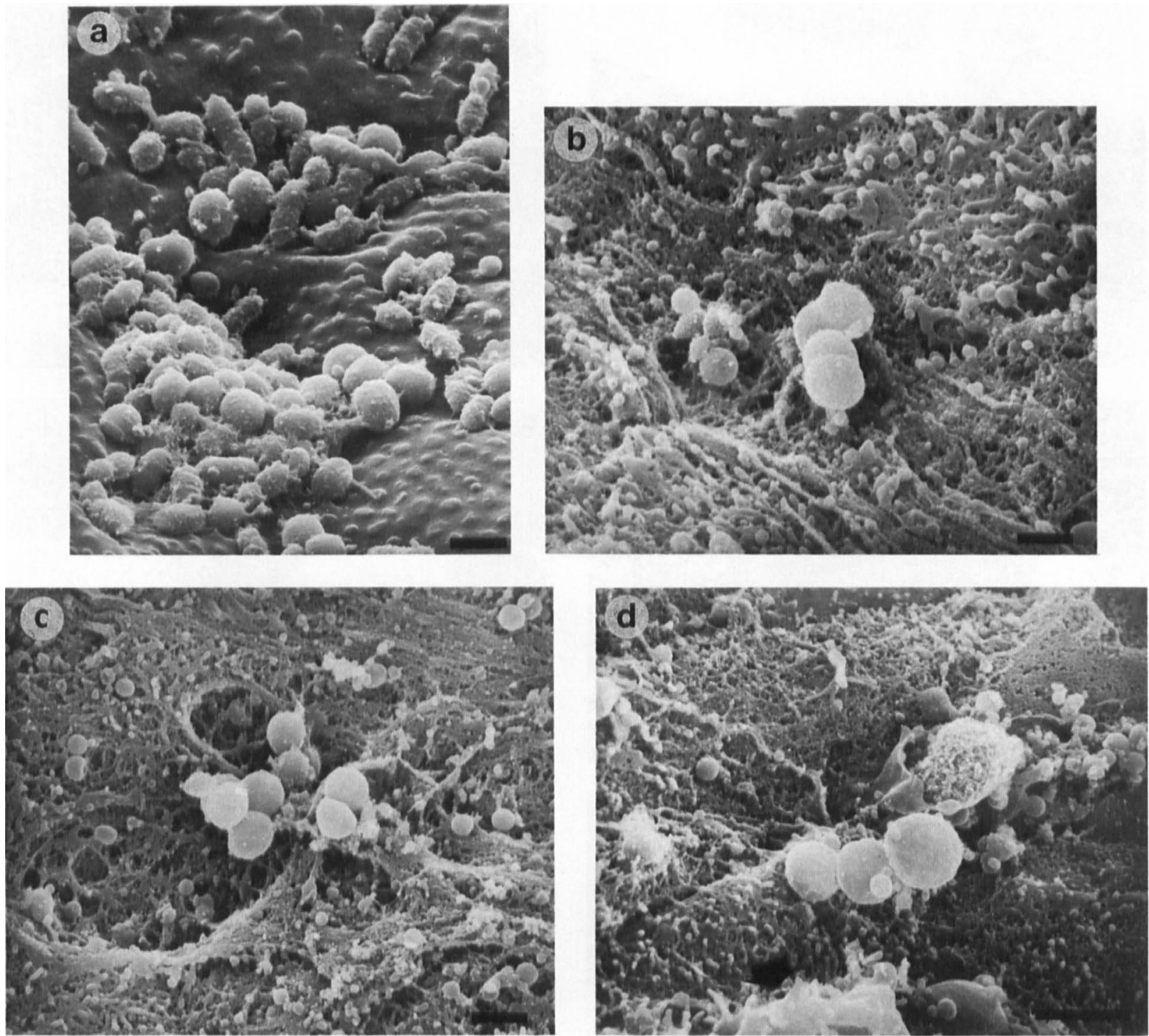

Fig. 4. SEM examination of the uterus: (a) surface of the uterine body $4 \mathrm{~h}$ after mice at late pro-oestrous were infected with Op variant; (b) surface of the uterine horn $12 \mathrm{~h}$ and (c) $24 \mathrm{~h}$ after mice at late pro-oestrous were infected with Op variant; (d) surface of the uterine horn $48 \mathrm{~h}$ after mice at dioestrous were infected with Tr variant. The arrow indicates a PMNL migrating toward a gonococcus (bar, $1 \mu \mathrm{m})$.

were infected at dioestrous with the $\operatorname{Tr}$ variant, both phenotypes were recovered in almost equal amounts.

\section{Discussion}

It has been reported ${ }^{25}$ that strains of gonococci isolated from infected women at the time of menses give rise primarily to $\mathrm{Tr}$ colonies, whereas isolates obtained in mid-cycle yield predominantly Op colonies. Moreover, a high frequency of complications such as pelvic inflammatory disease is observed at or near menses. ${ }^{33}$ These clinical observations indicate that the pathogenicity of gonococci in the female genital tract is closely related to the menstrual cycle. Although the colonial phase variation of isolates from cervical cultures has been studied at various stages of the menstrual cycle, little is known about the relationship between the infectivity of gonococcal variants and the menstrual cycle. Therefore, the present study was undertaken to clarify this relationship in studies with our mouse model of gonococcal genital infection.

The results obtained have demonstrated that $O p$ variants are infective in the genital tract of female mice only at late pro-oestrous, whereas the $\operatorname{Tr}$ variant was pathogenic at dioestrous as well as late prooestrous. Furthermore, Op variant colonies were predominant amongst isolates recovered from the uterus of mice infected at late pro-oestrous with either variant, whereas both phenotypes were recovered with equal frequency from animals infected at dioestrous with the $\operatorname{Tr}$ variant. These findings indicate that although $\operatorname{Tr}$ variants are infective at late pro-oestrous and dioestrous, intrauterine survival of the gonococci could be augmented by the phase variation from $\operatorname{Tr}$ to Op phenotype.

Gonococci of both phenotypes, loosely attached to the uterine surface, did not multiply there as much as in the uterine tissue, and transition from $\operatorname{Tr}$ to $\mathrm{Op}$ phase in uterine washes did not occur at the same rate 
Table IV. Recovery of $N$. gonorrhoeae 57-120 Op and Tr variants from the uterus of mice infected at late pro-oestrous or dioestrous*

\begin{tabular}{|c|c|c|c|c|}
\hline \multirow{2}{*}{$\begin{array}{l}\text { Colonial } \\
\text { type of } \\
\text { inoculum }\end{array}$} & \multirow{2}{*}{$\begin{array}{c}\text { Stage of } \\
\text { oestrous cycle } \\
\text { at inoculation }\end{array}$} & \multirow{2}{*}{$\begin{array}{c}\log _{10} \text { cfu/uterus } \\
\text { at day } 7\end{array}$} & \multicolumn{2}{|c|}{ Percentage of total colonies that were } \\
\hline & & & Op & $\mathrm{Tr}$ \\
\hline Op & $\begin{array}{l}\text { Late pro-oestrous } \\
\text { Dioestrous }\end{array}$ & $\begin{array}{l}5.43 \text { SD } 0.86+ \\
\text { Not recovered }\end{array}$ & $92 \cdot 8 \mathrm{SD} 10 \cdot 2$ & $4.8 \mathrm{SD} 9.6 \ddagger$ \\
\hline $\operatorname{Tr}$ & $\begin{array}{l}\text { Late pro-oestrous } \\
\text { Dioestrous }\end{array}$ & $\begin{array}{l}3.56 \text { SD } 0.53 \dagger \\
1.25 \text { SD } 0.24\end{array}$ & $\begin{array}{l}96.3 \text { SD } 11.2 \\
49.4 \text { SD } 9.8\end{array}$ & $\begin{array}{l}2 \cdot 5 \text { SD } 4.5 \ddagger \\
46 \cdot 2 \text { SD } 7 \cdot 7\end{array}$ \\
\hline
\end{tabular}

\footnotetext{
*Data were obtained from three separate experiments, and expressed as the mean (SD) for 10 mice.

$+\mathrm{P}<0.005$.

$\$ \mathrm{P}<0.001$.
}

as transition from $\operatorname{Tr}$ to Op phase in uterine homogenates. Furthermore, the number of gonococci in uterine washes decreased with time, compared with viable counts in uterine homogenates. Therefore, $\mathrm{Op}$ variants seemed to be heterogeneous, as some gonococci of the Op variant could invade the uterine epithelium but some were only attached to the surface of the uterus. This discrepancy between invasive and non-invasive types of Op variants could be explained by the differences in P. II proteins or other surface appendages such as pili.

Tr variants are known to be more virulent in the chicken embryo model ${ }^{34}$ and more resistant to human serum $^{35}$ than Op variants. Furthermore, Rest et al. ${ }^{36}$ have suggested that lectin-like components of gonococci expressing P. II can stimulate the oxidative burst of human phagocytes by which organisms are killed intracellularly. The present study has shown that PMNL infiltration did not occur in the genital tract after mice at late pre-oestrous were infected with either variant. Thus, it is unlikely that Op gonococci are killed by phagocytes in the genital tract of mice during late pro-oestrous. Moreover, Tr gonococci converted to $\mathrm{Op}$ within the uterus; phase variation rates were $>90 \%$ in mice infected at late pro-oestrous, and $c .50 \%$ in mice infected at dioestrous. This result contrasts with the report by Salit and Gotschlich ${ }^{34}$ that Op gonococci inoculated into the chicken embryo are replaced by $\mathrm{Tr}$ variants. We have isolated isogenic variants from seven clinical isolates of $N$. gonorrhoeae,

\section{References}

1. Black WJ, Schwalbe RS, Nachamkin I, Cannon JG. Characterization of Neisseria gonorrhoeae protein II phase variation by use of monoclonal antibodies. Infect Immun 1984; 45: $453-457$.

2. Blake MS, Gotschlich EC. Gonococcal membrane proteins: speculation on their role in pathogenesis. Prog Allergy $1983 ; 33$ : 298-313.

3. Lambden PR, Robertson JN, Watt PJ. The preparation and properties of $\alpha$ and $\beta$ pili from variants of Neisseria gonorrhoeae P9. J Gen Microbiol 1981; 124 : 109-117.

4. Salit IE, Blake M, Gotschlich EC. Intra-strain heterogeneity of gonococcal pili is related to opacity colony variance. $J$ Exp Med 1980; 151 : 716-725.

5. Swanson J. Studies on gonococcus infection. XIV. Cell wall protein differences among color/opacity colony variants of Neisseria gonorrhoeae. Infect Immun 1978; 21: 292-302.

6. Walstad DL, Guymon LF, Sparling PF. Altered outer mem- and tested them for infectivity and survival in the uterus. By comparing their behaviour in the genital tract, we have found that they are similar to isogenic variants of strain 57-120 (unpublished observation).

Histological studies showed clusters of Op gonococci in the subepithelial stroma to which phagocytic cells did not respond. P. II proteins were reported to increase inter-gonococcal adherence as well as attachment to epithelial cells. ${ }^{15-17}$ Therefore, clustering of Op gonococci may be attributable to $\mathrm{P}$. II proteins. Additionally, cluster formation might be associated with increasing oestrogenic activity in the genital tract, because oestrogen promotes the growth of Op gonococci ${ }^{24}$ and is more active at late pro-oestrous than at other stages of oestrous. However, P. II has proved to be a most intriguing group of highly variable and diverse proteins, and gonococcal variants, within a strain, may express none, one, or several different protein(s).$^{5,6,23}$ Moreover, P. II proteins may differ within a strain in both molecular weight and antigenicity. ${ }^{12,22,37}$ This may explain why Op variants exhibit differing abilities to invade uterine tissue. Thus, it is important to determine which of the P. II proteins can be induced or altered by oestrogen, and whether this P. II protein can contribute to cluster formation. Tentatively P. II could be involved in the intra-uterine survival of gonococci.

We thank Ms Iyuko Tanikawa for help in preparation of the manuscript.

brane protein in different colonial types of Neisseria gonorrhoeae. J Bacteriol 1977; 129: 1623-1627.

7. Buchanan TM, Pearce WA, Chen KCS. Attachment of Neisseria gonorrhoeae pili to human cells, and investigations of the chemical nature of the receptor for gonococcal pili. In: Brooks GF et al. (eds) Immunobiology of Neisseria gonorrhoeae. Washington DC, American Society for Microbiology. 1978: 242-249.

8. McGee ZA, Melly MA, Gregg CR et al. Virulence factors of gonococci: studies using human fallopian tube organ cultures. In: Brooks GF et al. (eds) Immunobiology of Neisseria gonorrhoeae. Washington DC, American Society for Microbiology. 1978: 258-262.

9. Watt PJ, Ward ME. The interaction of gonococci with human epitheiial cells. In: Roberts RB (ed) The gonococcus. New York, John Wiley \& Sons. 1977: 355-368.

10. James JF, Lammel CJ, Draper DL, Brown DA, Sweet RL, Brooks GF. N. gonorrhoeae attachment to eukaryotic cells. Sex Transm Dis 1983; 10: 173-179. 
11. King GJ, Swanson J. Studies on gonococcus infection. XV. Identification of surface proteins of Neisseria gonorrhoea correlated with leukocyte association. Infect Immun 1978; 21 : $575-584$

12. Lambden PR, Heckels JE, James LT, Watt PJ. Variations in surface protein composition associated with virulence properties in opacity types of Neisseria gonorrhoeae. J Gen Microbiol 1979; 114: 305-312.

13. Sugasawara RJ, Cannon JG, Black WJ, Nachamkin I, Sweet RL, Brooks GF. Inhibition of Neisseria gonorrhoeae attachment to $\mathrm{HeLa}$ cells with monoclonal antibody directed against a protein II. Infect Immun 1983; 42: 980985.

14. Watt PJ, Ward ME. Adherence of Neisseria gonorrhoeae and other Neisseria species to mammalian cells. In: Beachey EH (ed) Receptors and recognition, series B, volume 6, Bacterial adherence. London, Chapman and Hall. 1980 : 251-288.

15. Draper DL, Jammel CJ, Sweet RL, Brooks GF. Attachment of gonococcal outer membranes containing protein II variants to HeLa 229 cells. In: Schoolnik GK et al. (eds) The pathogenic neisseriae. Proceedings of the fourth international symposium. Washington DC, American Society for Microbiology. 1985: 271-275.

16. James JF, Lammel CJ, Draper DL, Brooks GF. Attachment of $N$. gonorrhoeae colony phenotype variants to eucariotic cells and tissue. In : Danielsson D, Normark S (ed) Genetics and immunobiology of pathogenic neisseria. Umea, University of Umea. 1980: 213-216.

17. Swanson J. Surface components associated with gonococcalcell interactions. In: Roberts RB (ed) The gonococcus. New York, John Wiley \& Sons. 1977: 369-401.

18. Draper DL, Donegan EA, James JF, Sweet RL, Brooks GF. In vitro modelling of acute salpingitis caused by Neisseria gonorrhoeae. Am J Obstet Gynecol 1980; 138: 996-1002.

19. Heckels JE. Role of surface proteins in the adhesion of Neisseria gonorrhoeae. In: Schlessinger D (ed) Microbiology. Washington DC, American Society for Microbiology. 1982: 301-304.

20. Lambden PR, Robertson JN, Watt PJ. Biological properties of two distinct pilus types produced by isogenic variants of Neisseria gonorrhoeae P9. J Bacteriol 1980; 141 : 393-396.

21. Swanson J. Studies on gonococcus infection. XII. Colony color and opacity variants of gonococci. Infect Immun 1978; 19: 320-331.

22. Swanson J. Colony opacity and protein II compositions of gonococci. Infect Immun 1982; 37: 359-368.
23. Lambden PR, Heckels JE. Outer membrane protein composition and colonial morphology of Neisseria gonorrhoeae strain P9. FEMS Microbiol Lett 1979; 5: 263-265.

24. Salit IE. The differential susceptibility of gonococcal opacity variants to sex hormones. Can J Microbiol 1982; 28 : 301306.

25. James JF, Swanson J. Studies on gonococcus infection. XIII. Occurrence of color/opacity colonial variants in clinical cultures. Infect Immun 1978; 19: 332-340.

26. Kita E, Matsuura $H$, Kashiba S. A mouse model for the study of gonococcal genital infection. J Infect Dis 1981; 143: 6770.

27. Kita E, Takahashi S, Yasui K, Kashiba S. Effect of estrogen (17 $\beta$-estradiol) on the susceptibility of mice to disseminated gonococcal infection. Infect Immun 1985; 49: 238-243.

28. Kellogg DS, Peacock WL, Deacon WE, Brown L, Pirkle CI. Neisseria gonorrhoeae. I. Virulence genetically linked to clonal variation. $J$ Bacteriol $1963 ; 85$ : 1274-1279.

29. Juni E, Heym GA. Simple method for distinguishing gonococcal colonial types. J Clin Microbiol 1977; 6: 511-517.

30. Yamai S, Obara Y, Nikkawa T, Shimoda Y, Miyamoto Y. Preservation of Neisseria gonorrhoeae by the gelatin-disc method. Br J Vener Dis 1979; 55: 90-93.

31. Thung PJ, Boot LM, Mühlbock O. Senile changes in the oestrous cycle and in ovarian structure in some inbred strains of mice. Acta Endocrinol (Copenh) 1956; 23: 8-32.

32. Johnson GD, Holborow EJ, Dorling J. Immunofluorescence and immunoenzyme techniques. In: Weir DM (ed) Handbook of experimental immunology, 3rd edn. Oxford, Blackwell Scientific Publications. 1978: 15.1-15.30.

33. Holmes KK, Counts GW, Beatty HN. Disseminated gonococcal infection. Ann Intern Med 1971; 74: 979-993.

34. Salit IE, Gotschlich EC. Gonococcal color and opacity variants: virulence for chicken embryos. Infect Immun 1978; 22: 359-364.

35. James JF, Swanson J. Color/opacity colonial variants of Neisseria gonorrhoeae and their relationship to the menstrual cycle. In Brooks GF et al. (eds) Immunobiology of Neisseria gonorrhoeae. Washington DC, American Society for Microbiology. 1978: 338-343.

36. Rest RF, Lee N, Bowden C. Stimulation of human leukocytes by protein $\mathrm{II}^{+}$gonococci is mediated by lectin-like gonococcal components. Infect Immun 1985; 50 : 116-122.

37. Swanson J, Barrera O. Immunological characteristics of gonococcal outer membrane protein II assessed by immunoprecipitation, immunoblotting, and coagglutination. $J$ Exp Med 1983; 157: 1405-1420. 